Alicante Journal of English Studies / Revista Alicantina de Estudios Ingleses

ISSN: 0214-4808 | e-ISSN: 2171-861X

Special Issue: Theatre and Performance Studies in English

No. 35, 2021, pages 43-58

https://doi.org/10.14198/raei.2021.35.02

\title{
"Come, Dark-eyed Sleep": Michael Field and the Performance of the Lyric as a Radical Fantasy
}

\author{
Mayron Estefan CANTILlo LuCuARA
}

\begin{abstract}
Author:
Mayron Estefan Cantillo Lucuara

Universitat de València, Spain

mayron.cantillo@uv.es

https://orcid.org/0000-0002-1298-8496

Date of reception: 27/02/2021

Date of acceptance: $21 / 06 / 2021$

Citation:

Cantillo Lucuara, Mayron Estefan. 2021. "“'Come, Dark-eyed Sleep": Michael Field and the Performance of the Lyric as a Radical Fantasy." Alicante Journal of English Studies 35: 43-58.

https://doi.org/10.14198/raei.2021.35.02

(C) 2021 Mayron Estefan Cantillo Lucuara

Licence: This work is licensed under a Creative Commons Attribution 4.0 International License (CC BY 4.0).

(c) (1)
\end{abstract}

\begin{abstract}
:
This article seeks to illustrate how the Michael Fields articulate their Sapphic poetry in Long Ago (1889) not only in keeping with their own Shakespearean aspirations and with Robert Browning's hybrid formula of dramatic lyrics, but also in connection with Jonathan Culler's theory of the lyric as a performative genre. Much recent scholarship has broken ground in the rediscovery and reappraisal of the Fields' literary stature, yet the general critical approach has been divisive in addressing their poetry and their verse dramas separately. Some critics have taken heed of how their lyrics in general exhibit an intrinsic dramatic temper, yet no systematic inquiry has discussed how this lyrical dramaticity is manifest in any particular instance. Thus, this article singles out Long Ago's second poem for its powerful performative energy, offering a close reading of each line, and demonstrating that it amounts to a hybrid dramatic lyric, as well as a tragic and transgressive performance in which a new Sappho takes centre stage as a Dionysian apologist of radical erotic fantasies.
\end{abstract}

Keywords: Michael Field; lyric; performance; Long Ago; Sappho 


\section{Introduction}

Fin-de-siècle authors Katharine Bradley and her niece Edith Cooper, a prolific duet who wrote pseudonymously as Michael Field, have attracted considerable critical attention, particularly since the 1990s. However, critics have generally approached their work from at least two separate directions. Their poetry has generated broad and diverse scholarship, including an entire monograph written by Marion Thain (2007), as well as multiple chapters and articles (Leighton 1992, White 1996, Prins 1999, O'Gorman 2006, Dellamora 2007, Madden 2007, Evangelista 2009, Olverson 2010, Cantillo-Lucuara 2018, Parker and Vadillo 2019). On the other hand, their dramatic production has also received enthusiastic attention from several other critics. Bickle (2010, 2012), Bristow (2019), Eastham (2011), Kirby (2017), Krisuk (2010), Lee (2019), Olverson (2015), and Parejo-Vadillo $(2007,2015)$ have made concerted efforts to amend and revise histories of late-Victorian drama with a view to foregrounding the Fields' plays, appraising their conspicuous originality, and empathically, revealing their intrinsic queer aesthetics. The overall result of this considerable scholarship is a now well-established view that Bradley and Cooper's lyrics and dramas constitute a large-scale repository of fluid, experimental, transgressive forms and ideas that resonate powerfully with our own cultural moment.

Nevertheless, it is striking that no approach has considered the two areas in unison or considered how Michael Field's lyric poetry is by no means separable from their dramatic writing. Not only are their numerous plays self-evidently poetic, written in the most classical or Elizabethan verse: their poems have at their core an inherent performative or dramatic energy. This lyrical dramaticity, the most salient concept in the present article, might be explained in light of two significant facts. Firstly, throughout the poems and plays of Michael Field there seems to be a general devotion to the dramatic word, a performative sense of rhetoric, a holistic understanding of life as/through dramatic tragedy, and more notably, a steady quest for Shakespearean excellence. Indeed, as Thain claims, the Fields always "saw themselves as dramatists and were caught up in the Victorian fervour for discovering a new Shakespeare" (Thain 2007, 8). In addition, as Biederstedt (1963) comments in one of the earliest doctoral studies on the Fields, they should be paired with their mentor and poet Robert Browning on account of their shared "distinctive manner of dramatizing a lyric" (43). This suggests that, for Bradley, Cooper and their eminent friend alike, their poetry should never be dissociated from their drama: both genres intersect in innovative and fruitful ways under a hybrid formula of particularly dramatic lyrics, as with Robert Browning's Dramatic Lyrics (1842), Dramatic Romances and Lyrics (1845), 
Men and Women (1855), Dramatis Personae (1862) Dramatic Idylls (1879) and Dramatic Idylls: Second Series (1880).

It is true that some critics have noted Michael Field's poetic theatricality, but it is done in a sweeping manner that fails to accurately explain where this special feature comes from or how it is textually manifested. In her reading of Long Ago, Michael Field's volume of Sapphic poetry published in 1889, Sturgeon (1922) was the first to claim that "their aim was simply to make short dramatic lyrics out of the scenes suggested to their imagination by the Sapphic fragments" (90, italics added). Similarly, in relation to the same volume, Thain (2007) has pointed out that the Fields' lyricism "dramatises [...] the gender drama played out in Long Ago" (60, italics added). In these critical assessments, though they acknowledge how dramatic Long Ago appears to be, how this dramaticity materialises is not addressed.

Framed within a general reflection on performance, this article aims to illustrate how the Michael Fields articulate their Sapphic poetry not only in line with the aesthetic parameters outlined above -their Shakespearean quest and their association with Browning, - but also in prospective connection with new theories. More particularly, I focus on Long Ago's second lyric in order to show how it lends itself to a close reading predicated upon Jonathan Culler's (2015) latest theory of the lyric. This genre, argues the British critic, often operates as a true performance in itself for several reasons: it has the performative power to deploy "language which accomplishes the act to which it refers" (15); it relies on ritualistic structures that make it sound as if "composed for reperformance" (37); it tends to appear to "us as something happening now, in the performative temporality of the lyric" (63); it seeks to achieve the perlocutionary effects of "moving readers, provoking reflection, leading them to act" (130); and finally, it functions performatively in that "it acts iterably through repeated readings and makes itself memorable" (131). In sum, the lyric should be understood not as a mere form of textuality printed on a silent page, but rather as a performative and ritualistic genre that involves the reader/audience as a necessary and immediate participant in the poetic utterance.

Premised on Culler's notion of the lyric performance, this article shows how Michael Field's second poem in Long Ago most effectively illustrates the dramaticity of their verse by shaping what could be viewed as a performance of erotic insomnia, anxiety and self-deception in which a reinvented Sappho becomes a persuasive dramatic persona through the use of apostrophes, imperative forms and other rhetorical devices of ritualistic iteration not only to seek divine assistance in her romantic tragedy or to make her disdainful beloved, a ferryman named Phaon, more attainable, but also to engage the reader in the memorable repetition of her assertive desire. This is lyric II in full: 
COME, dark-eyed Sleep, thou child of Night,

Give me thy dreams, thy lies;

Lead through the horny portal white

The pleasure day denies.

O bring the kiss I could not take

From lips that would not give;

Bring me the heart I could not break,

The bliss for which I live.

I care not if I slumber blest

By fond delusion; nay,

Put me on Phaon's lips to rest,

And cheat the cruel day! (1l. 1-12)

\section{First Quatrain: Performing Insomnia and Oneiric Desire}

Lyric II is sheer deception in its form. Its opsis, or what Culler (2015) refers to as "the ritualistic dimension of lines and stanzas" (252), creates an immediate yet misleading idea of order and harmony. Each of the lines finds its place within well-measured, rather symmetrical quatrains, which follow a visual, alternating pattern of two long lines (the first and the third), and other two short ones (the second and the fourth). Likewise, the poem's melos, or its "aural dimension" (Culler 2015, 35), reinforces the formal effect of order and harmony with a sound patterning based on an alternate $\mathrm{ABAB}$ sequence, a salient usage of plosive consonance, and a system of lexical and structural repetitions. Nevertheless, this overarching sense of formal regularity is rather deceptive: one might imagine the speaker of lyric II to be in a measured frame of mind, yet the content-based meaning of the poem hints at something radically different. It seems the Sapphic speaker is not a tranquil or carefree voice, but rather a desperate, vehement insomniac who hopes imperatively for the divinely orchestrated irruption of her beloved into her dreams. Accordingly, as soon as one enters the performance of lyric II, there arises a clear tension between form and content -between the pretension of emotional order and the reality of anxious insomnia.

The visuality of lyric II is, though, far more complex than its mere stanzaic arrangement. The notion of opsis, as reformulated by Culler, not only refers to poems as visual constructions, but also to the ways in which "the poem produces/ represents images" $(2015,256)$. As an optical construction, lyric II works as a uniform sequence of quatrains, yet the image it produces with its meanings is far from orderly and harmonious. Reading the poem as an imaginary ekphrasis 
or a visual performance, one can picture the Sapphic speaker fully awake, in utter solitude, in the middle of the night, anxiously brooding over her absent beloved, finding no release for her exuberant erotic energy, and praying for divine intervention in her tragic romance. This image, however, comes as no surprise given the long tradition of Sapphism, particularly from Ovid's Heroides onwards, for it is "the one bequeathed to posterity, for many centuries the definitive, [that of the] forlorn, love-struck and suicidal Sappho who has given up the love of women for an unrequited passion for a young man" (duBois 2015, 108).

What may surprise or engage any reader, though, is how immediate that traditional Sapphic persona feels in lyric II -her "performative temporality" as Culler puts it $(2015,63)$. Whether Lesbian, Ovidian, ancient or archaic, Sappho enacts her elegiac performance in the immediacy of the present time and, even more strikingly, in the urgency of the imperative forms she uses in poem II. The directness of her voice seems to contradict the titular pastness of the volume to the extent that there is no sense of long ago-ness whatsoever. Sappho's imperatives do not lose a single trace of their validity and vigour. No temporal distance comes between them and our reutterance of the poem. As we read or perform it aloud, lyric II sounds resolute and rhetorically persuasive. As readers, we can feel convinced that Michael Field's Sappho is in touch with us, synchronously sharing her despair and even hoping to trigger what O'Gorman (2006) identifies in his interpretation of Long Ago as our "universal sense of human emotions" (650). Indeed, in lyric II, Sappho manages to readily perform transhistorical feelings of erotic despair that would appeal to any sensitive reader/audience. In this sense, the Fields show how the lyric can achieve the perlocutionary effects of "moving readers, provoking reflection, leading them to act" (Culler 2015, 130).

In the first line of poem II ("COME, dark-eyed Sleep, thou child of Night"), we abruptly encounter Sappho calling on a pagan god with imperative force. Arguably, she finds herself all alone, desperate for romance yet self-insufficient, and hence inclined or even condemned to obtain assistance from a superior power. Since her lover lies far beyond her reach and control, she has no other choice but to apostrophise Hypnos, the god of sleep. The direct apostrophe she makes is so clear and emphatic that it sounds pleonastic. The invoked deity is characterised not only by the epithet of his dark eyes, but also by the specifying apposition of his origin. Here it seems rather tempting to speculate that the reference to Hypnos is so much more than an apostrophe. Sappho is probably limning a self-prosopography that likens herself to the god, making them share a space and their appearance. Put otherwise, one might imagine Sappho being immersed in the night and affected by a darkness around her eyes attributable to her erotic penury and insomnia.

Interestingly enough, the nocturnal god is addressed in a very straightforward manner. He becomes both an unmediated thou and a recipient of Sappho's orders. 
Her attitude is not that of a tearful supplicant, but rather of an assertive, or even aggressive, lover who disposes of all formalities and enjoins the deity to aid her. Sappho treats him as nothing but an equal and a necessary interlocutor who must attend to her wishes. This implicit portrayal, based on the first and subsequent imperative forms in lyric II, intimates something unexpected and disruptive in Sappho's lyric performance: she does not come across as a feeble, sleepless, bedconfined lover; instead, and despite her unreciprocated passion, she adopts a decisive voice that does not hesitate to make itself clearly heard, even among the gods. As will be discussed later, this image of a formidable and dangerous Sapphic performer systematically underlies the entirety of poem II from start to finish.

The second line ("Give me thy dreams, thy lies") can be read as the epitome or the climactic encapsulation of Sappho's erotic performance. Once she has commanded the god of sleep to visit her, she renders her order clearer and very specific. All she wishes is to fulfil her desire regardless of the means for doing so. She renounces the high values of rationality, truth, and reality, and chooses to be deceived by Hypnos and accept a simulacrum or a mimesis of this fulfilment. In a convincing combination of asyndeton and isocolon between "dreams" and "lies" with their iterated possessives, Sappho makes a radical metaphysical point: she can all too easily give up her barren reality of lovelessness for a fictitious, oneiric romance. In this voluntary renunciation, an ineluctable ontological conflict emerges between reality and non-reality with the former seemingly insufficient for Sappho, and the latter coming to guarantee her gratification. Thus, should Sappho gain access to the non-reality of dreams, they will certainly become her authentic emotional reality, and as a consequence, the previous antagonism loses its validity.

In Sappho's oneiric metaphysics, dream and reality or lie and truth are no longer at odds with one another, because her desire makes their synergism and co-presence possible. The mere dream of her beloved, although induced by Hypnos, promises to acquire some degree of reality that the lyric voice presumes to be sufficiently satisfactory. Likewise, the lie of her beloved's presence involves the potential to be felt as some kind of truth capable of assuaging Sappho's passion and despair. In her desiring consciousness, reality and veracity are no longer measured as factual magnitudes: they become ductile emotional categories whose respective boundaries are broken and obliterated in an attempt to reach some level of erotic fulfilment. This obliteration is what turns Sappho's idealised dreams and lies into legitimate affective variants of truth insofar as they render the object of her desire more real, accessible, and even controllable under the regime of her own imagination.

Dreams and lies operate as intermediary forces that can bring lover and beloved together within an order of oneiric idealism. Just like the traditional subject of 
Western epistemology, who accesses the object-world in the ontogenetic act of knowing, Sappho aspires to possess her beloved by dreaming him into pseudoexistence as an erotic idea. The mere idea of him would become, complete, or totalise her full reality. However, although it is clear that she would have the upper hand in her oneiric dimension, an inevitable question arises as to what position her beloved would occupy there. One can presume that he would be ontologically reduced, subdued, and dominated in the most objectifying and possessive way possible. Within Sappho's dreams, he would fall prey to an erotic economy of appropriation or reification. He would be debased into a static, passive, and dependent object at the mercy of Sappho's desire. As a result, what we see in this oneiric metaphysics is a transgressive gender performance-one in which Sappho acts as a domineering dreamer and liar while her beloved is implicitly reduced to a malleable, ideal object.

Such is Sappho's need to imprison or possess her beloved, that it becomes exponentially enhanced through the Homeric image of "the horny portal white" (1. 3). This line has at least three rhetorical devices at play: hyperbaton, anastrophe, and more importantly, what Heinrich Plett (2010) classifies as "meta-intertexteme" (281). The first figure appears as a prepositional phrase that separates the main verb from its direct object with the result that both references to the "portal" (1. 3) and "the pleasure" (1. 4) take pride of place. The anastrophe, which involves the postposition of the adjective "white" (1. 3), not only ascribes further, and literal, centrality to the "portal" (1. 3), but also enables the emergence of a prosodic oxymoron between "Night" (l. 1) and the adjective. Both rhetorical phenomena play a salient role in shaping and emphasising the Homeric figure of intertextual derivation (or meta-intertexteme) that can be pinpointed in the third line. Indeed, Michael Field's Sapphic speaker is alluding to what Homer presents in Book XIX of his Odyssey as the Ivory Gate of Sleep and the Horny Gate:

For two are the gates of shadowy dreams, and one is fashioned of horn and one of ivory. Those dreams that pass through the gate of sawn ivory deceive men, bringing words that find no fulfilment. But those that come forth through the gate of polished horn bring true issues to pass when any mortal sees them. But in my case, it was not from thence, methinks, that my strange dream came (l. 561-569).

Strikingly, Michael Field's portal seems to be a combination of the two Homeric gates, for it is "horny" and "white" at the same time. In a footnote to his edition of lyric II, Ivor C. Treby (2000) finds this combinatory intertext "unfortunate" (58), suggesting that the Fields should have referred solely to the Ivory Gate, with its symbolic linkage to fantasy and deceit, in order to reinforce the idea that their 
Sappho wants to inhabit an unreal world of erotic dreams and lies. However, it could be argued that, whether accidental or purposeful, the merging of the two gates into a single one helps to form and consolidate a more cogent idea: Sappho's dreams are endowed with the strategic ambivalence of being both deceitful and potentially conducive to an affective oneiric truth. In other words, Sappho's dreams are white and horny at once to the extent that she knows they are lies, but her immersion in them might bring her the erotic fulfilment she so lacks.

As mentioned above, there is a suggestive prosodic oxymoron between "Night" (1. 1) and "white" (1. 3). This figure becomes indispensable to our understanding of the last line in the first quatrain ("The pleasure day denies"). Sappho needs the god of sleep to make her hedonistic dreams come true and prevail over the sterility of her days, which, or who, are subject to a pathetic fallacy and receive the blame for her misery. A structural antithesis shows itself here. Lyric II clearly bases its own theory of the world on various binary constructs-internal chaos and formal order, night and day, darkness and whiteness, falseness and truth, dreams and reality. In each of these antithetical pairs, the former denotes what Sappho seeks and covets, the latter what she loathes. The resultant conception of life that she advocates is utterly unconventional: she privileges the deviant, perverse or irrational over what is atavistically viewed as ideal or righteous. It seems, therefore, that Sappho embraces the Dionysian at the expense of the Apollonian and becomes a possible Nietzschean apologist. This may sound farfetched, but the truth is that the Fields looked up to Nietzsche and upheld many of his aesthetic ideas to the point that, as Vadillo (2015) remarks, they were among the first generation of English intellectuals who "recognised Nietzsche's importance for modernity" (204). It is thus plausible to argue that Sappho's transgressive performance of desire in lyric II amounts to a Dionysian embrace of darkness, deceit, and dangerous dreams.

\section{Second Quatrain: Performing Unstable Gender Roles}

The second stanza of poem II radicalises the transgressive gender performance outlined above. Sappho now exposes her erotic psychology in an extreme light. Not only does she insist on keeping her dramatic imperative tone, but she also transforms her desire into an emasculating force of possession or capture: "O bring the kiss I could not take" (1. 5). In this line, Sappho specifies what she demands of Hypnos, limiting her request to just a kiss from her beloved. However, the kiss she covets is a metaphysical one, the product of a mere dream or a lie, and yet the very climax of Sappho's erotic antirealism. With this fictitious kiss, Sappho wishes to make up for her failure to possess the object of her desire. It seems, on account of the modal verb she employs in line 5 , that she has tried to kiss her 
beloved, but failed to do so. This vain attempt is certainly what motivates her to embrace an antirealist approach to love. Given that her beloved has rejected her once, all she can now do is settle for the idealism of making him hers and kissing him in her dreams. The bare infinitive used in line 5 effectively designates the type of action Sappho wishes to perform with her oneiric imagination: she wishes to take, capture, arrest or confine her beloved and keep him in her own interiority, against his will and with all the undertones of violence and despair behind this act of erotic imprisonment.

The sixth line of the lyric ("From lips that would not give") reinforces a previous central idea and presents a new one within what proves to be a paradoxical dis/order. On the one hand, there is a labial synecdoche that clearly refers to Sappho's beloved and confirms the tacit representation of him in the previous lines. He has so far been silhouetted as a prey, an oneiric prisoner, and at best an erotic dream or lie. Now, in the second quatrain, he is reduced to a pair of lips Sappho once tried to assault, but which withdrew from her. As a mere labial synecdoche, he becomes the potentially reified, passive, and receptive object of Sappho's violent kisses. On the other hand, although he is given quite an emasculated identity at first, Sappho's beloved gains a certain degree of action and autonomy in his evasive reaction to the aggressive Sapphic kiss. This disdain has two concomitant effects: the beloved manages to preserve his own space of freedom, but Sappho loses every prospect of romantic conquest and thus feels compelled to adopt a desperate creed of erotic antirealism -one in which her beloved no longer retains his freedom and falls under her oppressive economy of desire. This ideal oppression, alongside the labial synecdoche, may also intimate that Sappho's beloved is only superficially masculine. As the Ovidian convention has it, she falls for a ferryman whose name appears explicitly at the close of poem II. However, his true subjectivity seems to be so elusive, coy, and reducible to Sappho's extreme desire, that his identity might transcend heteronormative presuppositions in favour of more fluid, unstable, and amorphous gender categories_as though his synecdochic labiality were a poetic indicator of his potential femininity and hence of Sappho's homoerotic attraction towards his feminised persona. Using Thain's words, it could be argued that Sappho is not the only figure within Michael Field's "category-defying mixture of sexual imagery" (2007: 50): given his labial and emasculated representation in poem II, Phaon should also be added to this subversive mixture.

The seventh line of the poem ("Bring me the heart I could not break") brings together at least three rhetorical phenomena: a parallelistic reduplication of line 5 , a metonymic pleonasm, and a disintegrative metaphor of love as domination. Repetition seems to work as the best way for Sappho to articulate the urgency of her address to Hypnos. The imperative tone, the use of the same lexical and modal 
verbs, and the compact hypotaxis of relative clauses, all configure the rhetoric of despair that defines lyric II. Sappho insists on gaining access to her beloved at all costs and urges the god Hypnos to assist her once more. Now she targets her beloved's heart as the focal point of her fervent desire. He becomes nothing but a synecdochal victim that she once tried, and failed, to assault. Where he was just a mere pair of lips a line ago, he now has his identity configured as a potentially fragile heart that Sappho seeks to govern in a radical manner. At the end of line 7 , she makes use of a bare infinitive (break) that points to the crudest possible version of a metaphorical convergence between desire and destruction, love and loss. Indeed, with this infinitive, one cannot but corroborate what lyric II has since the outset represented as a direct equation of female desire with violence against a male object who becomes breakable and thus undergoes an extreme loss of identity and masculinity.

However, the second quatrain ends in a paradox: "The bliss for which I live" (1. 8). In its opsis, this is a standalone line, structurally identical to the final clause of the first quatrain, and yet syntactically dependent upon the main verb used in the immediately preceding sentence. In actual fact, the paradox arises from the imperative form "Bring" (1. 7), whose transitivity generates two semantically contradictory direct objects. The first object, as indicated above, involves a synecdoche that tacitly portrays Sappho's beloved in an objectifying and potentially castrating light. However, the second object, her erotic bliss, overturns the power dialectics intimated by the previous synecdoche. Now Sappho exposes her existential vulnerability in the plainest way by acknowledging that her very bliss hinges on her beloved -her life is shown to depend not on the factual possibility of conquering him, but merely on the fictional chance of dreaming of him. This paradoxical dialectics with Sappho in an ambiguous position of power between domination and dependence comes as no surprise, for it has formerly been disclosed through references to her beloved's disdain. Nonetheless, line 8 does make her position more manifest and even pitiable, evoking a miserable Sappho who craves erotic fulfilment but appears to force herself to settle for just an antirealist experience of this fulfilment.

\section{Third Quatrain: Reperforming Metaphysical and Physical Fantasies}

So far lyric II has devoted its first quatrain to the presentation of Sappho's erotic idealism or antirealism, and its second to the paradoxical articulation of how her antirealist approach to love translates into unstable gender categories. Now, the third quatrain seems to operate as an overarching conspectus of the previous stanzas that can be divided into three subparts. The first, comprising lines 9 and 10 , represents a return to the opening quatrain and a cogent reassertion of 
Sappho's self-deceiving idealism. Nevertheless, unlike the first quatrain, lines 9 and 10 sound far more performative, though for different reasons. Sappho's ego comes to the foreground in such a direct and unadorned manner, that she seems to be speaking to us with no sense of temporal distance, as if sharing an immediate hic et nunc with us-a genuine dialogue. The temporality and simplicity of her address seem extremely close or contiguous: "I care not if I slumber blest" (1. 9). Here her language is far from ornamental, elaborate or oblique. Rather, she feels unashamedly carefree and categorical in admitting that she has made the conscious choice to trade reality for fantasy. She openly acknowledges that her erotic success may only be a mere product of her sleep or slumber. This tragic form of anagnorisis, rather than affecting her, proves to be a natural, fully embraced fact for her. Sappho has made up her mind in favour of unreality.

There is more to line 9. Sappho ends it with a suggestive past participle that behaves almost like a catachresis or abuse, for it appears to betray its own semantic nature. Indeed, in their most common sense, the forms blest or blessing denote divine gifts, spiritual benefits or religious invocations. However, Sappho clearly abuses or misuses the sanctity of such terms and their denotations by implicitly charging them with subversive, profane connotations. Her idea of blessing is in no way devotional, but rather overtly secular and sexual. To her being blest means gratifying herself through erotic dreams or fantasies in which her beloved is under her control. In this respect, one might argue that either Sappho has no sense of spirituality and acts as an impious hedonist, or that her devotion is wholly Dionysian, and thus she expects her sighed-for blessing to come from ancient pagan gods -particularly those who proselytise all forms and varieties of pleasure.

As a syntactic structure, the tenth line is nothing but an agentive: "by fond delusion." It simply serves the purpose of determining the sort of blessing Sappho awaits -a blessing that puts her to sleep and fools her into believing that her fulfilling dreams are now her definitive reality. Nonetheless, transcending its mere syntactic function, line 10 adds further pathos to Sappho's counter-realism. She execrates her existence as preferably exchangeable for a "fond delusion." The noun she uses here not only sounds all too clear and consistent with the thematic substance of the entire poem, but also defines her attitude to life and sums up the creed of oneiric hedonism she advocates. Sappho is a committed self-deceiver, a radical self-illusionist, and an intentionalist in her deliberate will to renounce truth in favour of a love unilaterally lived in her dreams. More interestingly, the adjective "fond" reveals Sappho's tragic awareness that her romantic aspirations are not just self-deceitful, but naive and arguably absurd. On account of their acknowledged fondness or foolishness, Sappho's dreams will most likely fail to match her libidinous expectations. 
The second subpart of the closing quatrain is constituted by line 11 alone, in which Sappho mainly reverts to the thematic line of the second stanza. Indeed, she reemploys a violent metaphor of erotic possession, together with an objectifying synecdoche, in order to insist on her need to at least gain an oneiric yet bodily experience of her beloved: "Put me on Phaon's lips to rest" (l. 11). The labial synecdoche, cohesively readopted from line 6, shows again that Sappho's desire entails no modesty or purity. Rather, her sense of love is clearly erotic, material, corporal. The emphasis on her beloved's lips intimates this deliberate corporality. It seems Robert Browning detected this sexual innuendo when he read the first manuscript and suggested replacing the labial synecdoche with a subtler and tenderer reference to another body part: "Why not 'in arms'?" (Treby 2000, 58). However, the Fields preferred to stick to their emasculating discourse of labiality in line with the second quatrain.

In keeping with Sappho's systemic subversion of gender conventions, line 11 exerts noticeable metaphoric violence on her beloved, who now receives the very first onomastic mention in Long Ago. He has formerly been a mere pronoun, a synecdoche, and an eroticising absence at best, but now his name appears in order to humanise his identity to some degree-or at least he ceases to be just Sappho's beloved and becomes more individualised and nameable. Nevertheless, the fact that Phaon is endowed with a proper subjectivity of his own does not have a lasting effect. Whether nameful or nameless, he continues to indirectly undergo Sappho's erotic violence. The imperative verb "put" and the preposition "on" are distinct indications that her desire is a tyrannical force and an imposition upon its object. In her imagination there is no intention to embrace Phaon or fall into his arms, as Browning would have preferred. Instead, she wishes to put herself or superimpose herself on him regardless of his will. Interpreted as a catachresis, the infinitive that Sappho uses at the end of line 11 reinforces the tacit representation of erotic despotism. Her idea of rest does not seem to indicate repose, stillness, or mere habitation. More plausibly, Sappho is abusing the infinitive and perverting it into a catachresis that equates rest to power, control, action, motion, and even sexual domination. Her definition of rest works simply as a euphemism for her oppressive lust.

The third subpart of the last quatrain corresponds to its closing line: "And cheat the cruel day" (1. 12). Here Sappho makes a semantic iteration that refers us back to the opening stanza and transforms the entire poem into a circular composition-a literal yet poetic circumlocution. It seems clear that Sappho is ensuring her address to the god Hypnos ends with a repetitive, and expectedly imperative, insistence on her embrace of self-delusive idealism. However, unlike previous articulations of this idealism, the final line argues for it in a cruder way, with the unambiguous, detrimental verb "cheat." Sappho has no reservations 
in stating that she wants to be cheated, dislocated from reality, and sunk into a pseudo-world of dreams. This self-inflicted fantasy does not necessarily place her in a weak position, though. After all, she always maintains the upper hand as the active, voracious, and radical dreamer, while her beloved is ideally represented as her potential prisoner and cheated prey. Cheating thus becomes a powerful defence mechanism or survival strategy that Sappho devises in the face of her loveless facticity_against what she styles as "the cruel day." This simple phrase constitutes at once a pathetic fallacy, a reformulation of line 4, and a metaphoric expression of Sappho's dichotomous conception of existence. In her view, existence appears to boil down to a marked antithesis between day and night with the former symbolising a ruthless form of emotional death and the latter promising her a possibility of erotic success-even if this success is but mere fiction. Sappho hopes to exist in an eternal night of ideal fantasies.

\section{Conclusions}

Sturgeon and Thain have taken note of a certain dramaticity behind Michael Field's verse, particularly in their Sapphic volume Long Ago. Indeed, even the quickest reading of a poem of theirs triggers what Culler would call a series of perlocutionary effects that transform the very experience of reading into a performance in its own right. Lyric II is a paradigmatic case in point of Michael Field's poetic theatricality. As demonstrated in this article, when reading lyric II, we enter a direct dialogue with a firm-voiced Sappho who engages us not only in her immediately present temporality, but also in her tragic context of lovelessness and despair. This context is not explicitly described, but it does result from the urgent rhetoric of the repetitious imperative anaphors that Sappho uses to structure nearly every line of the lyric and to convey her sore need to gain any sort of access to her absent beloved. Consequently, and as if the poem were an ekphrasis from start to finish, we are automatically led to form a mental yet performative picture wherein Sappho becomes a desperate insomniac longing to dream of her Phaon with the aid of the god Hypnos.

The pictorial and performative power of poem II makes us bear direct witness to Sappho's romantic suffering, listen to her address in an unmediated hic et nunc, and even share with her a universal, transcendental affect. Once in this position of readerly empathy, we are invited or exposed to a performance of radical ideas and emotions dramatised by Sappho. Given its rhetorical complexity, the lyric performance unfolds in two different yet complementary directions. On the one hand, there is a Sappho that acts as a radical metaphysician, despising the Apollonian regime of truth and reality, embracing the Dionysian forces of darkness and delusion, redefining desire as an imaginative experience, and therefore 
advancing a peculiar hedonism that offsets the facticity of erotic deprivation with the mere promise of a fictitious, subjective, and immanent pleasure. In this sense, Sappho addresses both us and her god from the staunch yet self-detrimental perspective of a lover who refuses to remain weak in the face of tragedy and devises a strategic metaphysical plan to possess her reticent beloved.

On the other hand, there is another dimension to Sappho's performance of desire. Not only does she uphold a firm belief in ontological self-deception as a source of erotic gratification, but she also adds a transgressive gender view to this same belief. As lyric II reveals, especially in its second quatrain, Sappho's erotic metaphysics of dreams and lies is informed by a whole synecdochic dialectics in which she breaches all gender conventions, transforms her beloved into a passive object, and portrays herself as a sublime woman-almost a femme fatale-who wishes to possess, control, and dominate him. Although, or because, she is well aware of her vulnerable position as an unrequited lover, Sappho represents her beloved Phaon as a pair of tempting lips and thus makes him occupy a nonnormative space of objectified effeminacy. It may seem a stretch, but the fact that Phaon comes across as an emasculated figure suggests that Sappho's desire is only superficially heteroerotic and potentially homoerotic in that her beloved stands closer to femininity than to masculinity. What is clear, however, is that lyric II reads as a radical performance in which Sappho speaks directly to her timeless readers and welcomes them to an eternal night of metaphysical and subversive fantasies.

\section{Works cited}

Bickle, Sharon. 2010. "Victorian Mænads: On Michael Field's Callirrhoë and Being Driven Mad." The Michaelian 2. Available at: http://www.thelatchkey.org/Field/ MF2/bicklearticle.htm.

—. 2012. "Disability and gender in the visual field: seeing the subterranean lives of Michael Field's William Rufus (1885)." Victorian Literature and Culture 40 (1): 137-152. https://doi.org/10.1017/S1060150311000283

BLAin, Virginia. 1996. "Michael Field, the two-headed nightingale: Lesbian Text as Palimpsest." Women's History Review 5 (2): 239-257. https://doi. org/10.1080/09612029600200117

Bristow, Joseph. 2019. "Michael Field's 'Unwomanly Audacities': Attila, My Attila!, Sexual Modernity and the London Stage." In Parker and Parejo Vadillo 2019, 123-150.

Burroughs, Catherine, ed. 2019. Closet Drama: History, Theory, Form. New York and London: Routledge. https://doi.org/10.4324/9781315107394

Cantillo-Lucuara, Mayron E. 2018c. "Michael Field's Sapphism: An Ontology of the Feminine in Long Ago (1889)." Lectora. Revista de Dones i Textualitat 24: 205-222. https://doi.org/10.1344/Lectora2018.24.12 
—. 2018b. "Michael Field's Long Ago (1889) as a Paradigm of Intertextual Theory: From Strangeness to Metaxology." Cuadernos de Investigación Filológica 44: 185210. https://doi.org/10.18172/cif.3442

—. 2018c. "Michael Field's Long Ago (1889): A Transcendental Mythopoesis of Desire and Death." ES Review. Spanish Journal of English Studies 39: 69-96. https://doi. org/10.24197/ersjes.39.2018.69-96

Culler, Jonathan. 2015. Theory of the Lyric. Cambridge, MA: Harvard University Press. https://doi.org/10.4159/9780674425781

DAu, Duc and Shale Presto, eds. 2015. Queer Victorian Families: Curious Relations in Literature. New York and London: Routledge. https://doi. org/10.4324/9781315762067

Dellamora, Richard. 2007. "The Sapphic Culture of Michael Field and Radclyffe Hall." In Stetz and. Wilson 2007, 127-136.

DuBors, Page. 2015. Sappho. London and New York: I. B. Tauris. https://doi. org/10.5040/9780755695195

EastHAm, Andrew. 2011. "Bacchic Transference and Ecstatic Faith: Michael Field's Callirrhoë and the Origins of Drama." Women's Studies 40: 491-512. https://doi.org/10.1080/00497878.2011.561743

EHNenn, Jill R. 2008. Women's Literary Collaboration, Queerness and Late-Victorian Culture. London: Routledge.

Evangelista, Stefano. 2009. British Aestheticism and the Ancient Greece: Hellenism, Reception, Gods in Exile. Basingstoke: Palgrave Macmillan. https://doi. org/10.1057/9780230242203

FIeLD, Michael. 1889. Long Ago. London: George Bell and Sons.

Homer. 1919. The Odyssey with an English Translation by A.T. Murray, PH.D. Cambridge, MA., Harvard University Press.

KirBy, J. 2017. "Heroines, Anti-Heroines and New Women: The Early Drama of Michael Field, 1884-1895." PhD diss., University of Westminster.

KRISUK, Jennifer. 2010. "Moving beyond 'Michael Field': Identity through anonymity in Borgia." The Michaelian 2, http://www.thelatchkey.org/Field/MF2/krisukarticle. htm

LeE, Michele. 2019. "Michael Field's Stephania: The closet drama as a space for female fortitude and artistic agency." In Burroughs 2019, 68-80.

Leighton, Angela. 1992. Victorian Women Poets: Writing Against the Heart. Oxford: Harvester Wheatsheaf.

Madden, Ed. 2008. Tiresian Poetics: Modernism, Sexuality, Voice, 1888-2001. Madison: Fairleigh Dickinson University Press.

O'Gorman, Francis. 2006. "Michael Field and Sapphic Fame: 'My dark-leaved laurels will endure." Victorian Literature and Culture 34 (2): 649-661. https://doi. org/10.1017/S1060150306051369 
Olverson, D. Tracy. 2010. Women Writers and the Dark Side of Late-Victorian Hellenism. Basingstoke: Palgrave Macmillan. https://doi.org/10.1057/9780230246805

—. 2015. "Michael Field's Dramatically Queer Family Dynamics." In Dau and Preston 2015, 57-76.

Parker, Sarah and A. Parejo Vadillo, eds. 2019. Michael Field: Decadent Moderns. Ohio: Ohio University Press.

PletT, Heinrich. 2010. Literary Rhetoric: Concepts - Structures - Analyses. Leiden: Brill. https://doi.org/10.1163/ej.9789004171138.i-320

Prins, Yopie. 1999. Victorian Sappho. New Jersey: Princeton University Press.

SteTz, Margaret. D. and Cheryl A. Wilson, eds. 2007. Michael Field and Their World. Birmingham: The Rivendale Press.

Sturgeon, Mary. 1922. Michael Field. London: George G. Harrap \& Co

Thain, Marion. 2007. 'Michael Field' Poetry, Aestheticism, and the Fin de Siècle. Cambridge: Cambridge University Press. https://doi.org/10.1017/CBO9780511484933

Thain, Marion and A. Parejo Vadillo, eds. 2009. Michael Field, The Poet. Published and Manuscript Materials. Toronto: Broadview Editions.

Thomas, Kate. 2019. "Vegetable Love: Michael Field's Queer Ecology." In Parker and Vadillo, eds., 25-46, Ohio: Ohio University Press.

Treby. Ivor C. 2000. Music and Silence: The Gamut of Michael Field. Suffolk: De Blackland Press.

Vadillo, A. Parejo. 2007. "Outmoded Dramas: History and Modernity in Michael Field's Aesthetic Plays.” In Stetz Margaret and Cheryl A. Wilson 2007, 237-248.

-. 2015. "This hot-house of decadent chronicle': Michael Field, Nietzsche and the Dance of Modern Poetic Drama." Women: A Cultural Review 26 (3): 195-220. https://doi.org/10.1080/09574042.2015.1079994

White,Chris. 1996. "FleshandRoses:MichaelField's MetaphorsofPleasureandDesire." Women's Writing 3 (1): 47-62. https://doi.org/10.1080/0969908960030104 